Article

\title{
Degradation Behavior of Micro-Arc Oxidized ZK60 Magnesium Alloy in a Simulated Body Fluid
}

\author{
Ze-Xin Wang ${ }^{1}$, Guan-Qun Chen ${ }^{1}$, Liang-Yu Chen ${ }^{2}$, Lei $X u^{1}$ and Sheng $\mathrm{Lu}{ }^{1, *}$ \\ 1 School of Materials Science and Engineering, Jiangsu University of Science and Technology, \\ Zhenjiang 212003, China; xxkissbaby@126.com (Z.-X.W.); cgq402@126.com (G.-Q.C.); \\ wzxlwg@126.com (L.X.) \\ 2 School of Science, Jiangsu University of Science and Technology, Zhenjiang 212003, China; \\ lychen@just.edu.cn \\ * Correspondence: lusheng_ktz@just.edu.cn; Tel.: +86-511-8440-3699
}

Received: 15 August 2018; Accepted: 12 September 2018; Published: 14 September 2018

\begin{abstract}
Bio-ceramic coatings were synthesized on ZK60 magnesium alloys by micro-arc oxidation (MAO). The degradation behavior of the ZK60 alloys with and without MAO coating in the simulated body fluid (SBF) was studied. The samples were characterized by means of scanning electron microscopy (SEM), laser scanning confocal microscopy (CLSM), and X-ray diffraction (XRD). Electrochemical impedance spectroscopy (EIS) was used to study the degradation behavior. The results showed that the porous MAO coating mainly consisted of $\mathrm{MgO}, \mathrm{Mg}_{2} \mathrm{SiO}_{4}, \mathrm{Mg}_{3}\left(\mathrm{PO}_{4}\right)_{2}$, and $\mathrm{CaCO}_{3}$. The $\mathrm{pH}$ values of both coated and uncoated samples increased over time. However, the $\mathrm{pH}$ values of the SBF for coated samples always maintained a lower level compared with those for the uncoated samples. Thereby, the coated samples showed a much lower degradation rate. After immersion in SBF for 5 days, corrosion product containing $\mathrm{Ca}$ and $\mathrm{P}$ was found on both samples, while the deposition was more active on the coated samples. The degradation models for the uncoated and coated samples in the SBF are also proposed and discussed.
\end{abstract}

Keywords: ZK60 magnesium; MAO; SBF; degradation; degradation model

\section{Introduction}

Magnesium (Mg) is an essential element for the human body, and takes part in more than 300 biochemical reactions in the body [1-4]. Compared with other implants, the density and elastic modulus of $\mathrm{Mg}$ alloys are much closer to human bones, and thus stress shielding can be avoided [5-9]. Mg alloys have a good biocompatibility and no cytotoxicity [10-12], and can degrade in vivo which obviates the need for a second surgery $[13,14]$. Furthermore, they can induce the formation of bone [15], and thus the damaged bone can be healed more quickly [16-19]. Therefore, $\mathrm{Mg}$ and its alloys have gained extensive attention as biomedical materials. However, the degradation rate of $\mathrm{Mg}$ alloys is much faster than the healing rate of the damaged bone $[20,21]$. Just like the other biomedical materials, a further treatment is always needed [22,23].

In general, the degradation rate of alloys can be controlled mainly by tailoring their compositions or by conducting surface treatments [24,25]. Surface treatment can effectively improve the corrosion resistance of alloys, and conversion coating, anodizing, micro-arc oxidation (MAO), and other technologies are representatives of this treatment [26-30]. Hakimizad et al. [31] reported that micro-arc oxidation coatings are formed by numerous short-lived micro-arc discharges on the entire surface occurring at voltages higher than the breakdown voltages of the oxide coating, the hard, thick, and adherent oxide coatings on light metals (e.g., $\mathrm{Al}$ and $\mathrm{Mg}$ ) and on their alloys can be obtained by micro-arc oxidation technology. Benjamin et al. [32] found that the corrosion resistance 
of AZ31 Mg alloys in simulated body fluid (SBF) was significantly improved after MAO treatment. Sankara Narayanan et al. [33] reported that MAO treatment could improve the hardness and bonding strength of $\mathrm{Mg}$ substrate. Therefore, micro-arc oxidation is a convenient technique to obtain porous and corrosion-resistant bio-ceramic coatings.

A thorough understanding of the corrosion behavior of $\mathrm{Mg}$ alloys in the physiological environment is a basic requirement in order to control their degradation rates [34]. A number of researchers have investigated the corrosion behavior of $\mathrm{Mg}$ alloys. Gu et al. [19] studied the corrosion product layer formed on the AZ31 alloy surface during immersion in SBF, and found that it enhanced the alloy's corrosion resistance. A corrosion model proposed by $\mathrm{Gu}$ et al. [35] indicated that the corrosion resistance of a coating depends on the thickness of the compact layer and the compactness of the MAO coating. Lin et al. [36] demonstrated that the degradation of the MAO coating was accompanied by the formation of a degradation layer and a Ca-P deposition layer, which would improve the biocompatibility of the coating surface.

To our knowledge, most studies focus on the corrosion behavior of MAO coatings on AZ91 or AZ31 Mg alloys (whose chemical composition contain $\mathrm{Al}$, well-known as a main inducing element to Alzheimer's disease) in SBF [37,38]. Some researchers have chosen to develop their own self-designed Mg alloys with bio-safe alloying elements [39-41], taking a great deal of R\&D time and cost. ZK60 (Mg-Zn-Zr) Mg alloy is not only commercially available, but its alloying element Zn is a trace element essential to the human body, and $\mathrm{Zr}$ (another alloying element)-based materials (e.g., $\mathrm{ZrO}, \mathrm{Zr}-\mathrm{Cu}-\mathrm{Al}-\mathrm{Ag}$ alloy, $\mathrm{Zr}-2.5 \mathrm{Nb}, \mathrm{Zr}-1.5 \mathrm{Nb}-1 \mathrm{Ta}$ crystalline alloys, etc.) exhibit satisfactory biocompatibility [42-44]. Therefore, considering both safety and economy, it is essential to understand the degradation behavior of micro-arc-oxidized ZK60 Mg alloy in SBF.

In this work, MAO was conducted on ZK60 Mg alloy to prepare bio-ceramic coatings in an optimized electrolyte system. Both coated and uncoated samples were immersed in SBF for 30 days. SEM and laser scanning confocal microscopy (CLSM), were used to observe the morphologies of the samples. XRD and Fourier transform infrared spectroscopy (FTIR) were employed to investigate the compositions of coatings and corrosion products. The corrosion behavior was studied by electrochemical test paired with a static weight-loss method. Finally, in vitro SBF soaking was conducted to analyze the degradation behavior of the samples with and without MAO coating.

\section{Materials and Methods}

\subsection{Coating Preparation}

Commercially available rolled ZK60 Mg alloy (Mg-5.8 wt \% Zn- $0.45 \mathrm{wt} \% \mathrm{Zr}$ ) was used as the substrate in this work. The samples were cut into $5 \mathrm{~mm} \times 20 \mathrm{~mm} \times 20 \mathrm{~mm}$ plates by means of an electric arc CNC wire-cut machine (Haima Numerical Control Equipment Co., Ltd., Suzhou, China) and then ground up to 1200 grits using SiC paper (Wuhan advanced technology Co., Ltd. Wuhan, China), ultrasonically cleaned, rinsed with distilled water, and dried in the air.

MAO was conducted on ZK60 samples under constant-current mode in a self-developed compound electrolyte with a composition of $6 \mathrm{~g} / \mathrm{L} \mathrm{Na}{ }_{2} \mathrm{SiO}_{3} \cdot 9 \mathrm{H}_{2} \mathrm{O}, 0.5 \mathrm{~g} / \mathrm{L} \mathrm{Ca}\left(\mathrm{CH}_{3} \mathrm{COO}\right)_{2} \cdot \mathrm{H}_{2} \mathrm{O}$, $0.8 \mathrm{~g} / \mathrm{L}\left(\mathrm{NaPO}_{3}\right)_{6}, 0.5 \mathrm{~g} / \mathrm{L} \mathrm{NaH}_{2} \mathrm{PO}_{4} \cdot \mathrm{H}_{2} \mathrm{O}$, and $2.8 \mathrm{~g} / \mathrm{L} \mathrm{NaOH}$. Current density, frequency, positive duty ratio, negative duty ratio, and reaction time were respectively set as $20 \mathrm{~A} / \mathrm{dm}^{2}, 500 \mathrm{~Hz}, 40 \%, 60 \%$, and $15 \mathrm{~min}$.

\subsection{Immersion Test}

The coated and uncoated samples were immersed in an SBF with ion concentrations almost equal to human blood plasma (Table 1) for 30 days. Three samples were tested to evaluate one time spot of corrosion time. The reagents and dose for preparing $1000 \mathrm{~mL}$ SBF are shown in Table 2. The reagents were dissolved one-by-one in distilled water at $36.5 \pm 0.5^{\circ} \mathrm{C}$ in the order shown in Table 2. The $\mathrm{pH}$ value was adjusted to 7.45 with Tris and $\mathrm{HCl}$ solution at $36.5 \pm 0.5^{\circ} \mathrm{C}$. 
Table 1. Ion concentrations of simulated body fluid (SBF) and blood plasma (mmol/L).

\begin{tabular}{ccccccccc}
\hline Solution & $\mathbf{N a}^{+}$ & $\mathbf{K}^{+}$ & $\mathbf{M g}^{2+}$ & $\mathbf{C a}^{2+}$ & $\mathbf{C l}^{-}$ & $\mathbf{H C O}_{3}{ }^{-}$ & $\mathbf{H P O}_{4}{ }^{2-}$ & $\mathbf{S O}_{4}{ }^{2-}$ \\
\hline SBF & 142.0 & 5.0 & 1.5 & 2.5 & 148.8 & 4.2 & 1.0 & 0.5 \\
Blood Plasma & 142.0 & 5.0 & 1.5 & 2.5 & 103.0 & 27.0 & 1.0 & 0.5 \\
\hline
\end{tabular}

Table 2. Reagents and doses for $1000 \mathrm{~mL}$ SBF.

\begin{tabular}{cccccccc}
\hline Reagent & $\mathbf{N a C l}$ & $\mathrm{NaHCO}_{3}$ & $\mathbf{K C l}$ & $\mathbf{K}_{2} \mathbf{H P O}_{\mathbf{4}} \cdot \mathbf{3} \mathbf{H}_{\mathbf{2}} \mathbf{O}$ & $\mathbf{M g C l}_{\mathbf{2}} \cdot \mathbf{6 H} \mathbf{H}_{\mathbf{2}} \mathbf{O}$ & $\mathbf{1 . 0} \mathbf{M}-\mathbf{H C l}$ & $\mathbf{N a}_{2} \mathbf{S O}_{4}$ \\
\hline Quantity & $8.035 \mathrm{~g}$ & $0.355 \mathrm{~g}$ & $0.225 \mathrm{~g}$ & $0.231 \mathrm{~g}$ & $0.311 \mathrm{~g}$ & $39 \mathrm{~mL}$ & $0.072 \mathrm{~g}$ \\
\hline
\end{tabular}

Each sample was soaked in a plastic beaker containing $120 \mathrm{~mL}$ of SBF in a thermostat water bath at $36.5 \pm 0.5^{\circ} \mathrm{C}$. The ratio of the sample's surface area $\left(\mathrm{cm}^{2}\right)$ to SBF volume $(\mathrm{mL})$ was 1:10 [45-47]. The $\mathrm{pH}$ values of the SBFs of three parallel tests were recorded to obtain an average value every $24 \mathrm{~h}$, and the SBFs were refreshed after recording. A couple of coated and uncoated samples were removed from the SBF for further examination every 5 days. The corrosion rate of the coating was characterized by weight loss ratio. In the equation below, $R_{\mathrm{wt}}$ is the weight loss ratio, $M$ is the quality of the sample before corrosion, and $M_{1}$ is the quality of the sample after corrosion:

$$
R_{\mathrm{wt}}=(M-M 1) / M \times 100 \%
$$

\subsection{Characterization}

Scanning electron microscopy (SEM, JSM-6480, JEOL, Tokyo, Japan) was used to observe the surface morphology and cross section morphology of the coatings. A laser scanning confocal microscope (CLSM, OLS4000, Olympus, Tokyo, Japan) was used to measure the roughness of the coated samples by taking the average value of five points. X-ray diffraction (XRD, OxfordCMI233, $40 \mathrm{~kW}$, SHIMADZU, Tokyo, Japan) analysis was carried out with monochromatic $\mathrm{Cu} \mathrm{K}_{\alpha}$ radiation over a $2 \theta$ range of $20^{\circ}$ to $90^{\circ}$ with a scanning rate of $4^{\circ} / \mathrm{min}$. Electrochemical impedance spectroscopy (EIS, EG\&G M283, AUTOLAB, Bern, Switzerland) was used to study the degradation behavior of samples. The EIS tests were conducted in SBF at $36.5 \pm 0.5^{\circ} \mathrm{C}$, at the open circuit potential (OCP), with a $10 \mathrm{mV}$ alternating signal from $100 \mathrm{kHz}$ to $100 \mathrm{mHz}$. The equivalent circuits were used to fit the EIS data.

After the immersion test in SBF, the corrosion products were measured by FT2000 type FTIR (AGILENT, Santa Clara, CA, USA) in the spectral range $400-4000 \mathrm{~cm}^{-1}$. The chemical compositions of corrosion products were deduced by the form and position of absorption peaks. The hydrophilicities of the coatings were measured by a contact angle measuring instrument, JC2000D (Shanghai auto-lab technology Co., Ltd., Shanghai, China).

\section{Results}

\subsection{Characterization and Properties of the MAO Coating}

The surface and cross-sectional morphology of the MAO coatings are shown in Figure 1. It can be seen that the coating featured micro-pores with diameters ranging from 2 to $13 \mu \mathrm{m}$, melts, and cracks (Figure 1a). Because of the repeating breakdown at the same position of the coating, small pores in big pores were observed, as indicated by point A in Figure 1a. Meanwhile, some areas of the coating melted due to the high temperature during MAO, and then solidified on the surface. It can be seen from the cross-sectional morphology of the MAO coating that the coating was composed of a dense inner layer and a porous outer layer with a distinguishable boundary (Figure 1b). The outer loose layer was characterized with larger pores and more micro cracks, while the dense layer was more compact with fewer micro-cracks. The thickness of the coating was about $82 \mu \mathrm{m}$, with two types of micro-pores: blind-holes and through-holes. 

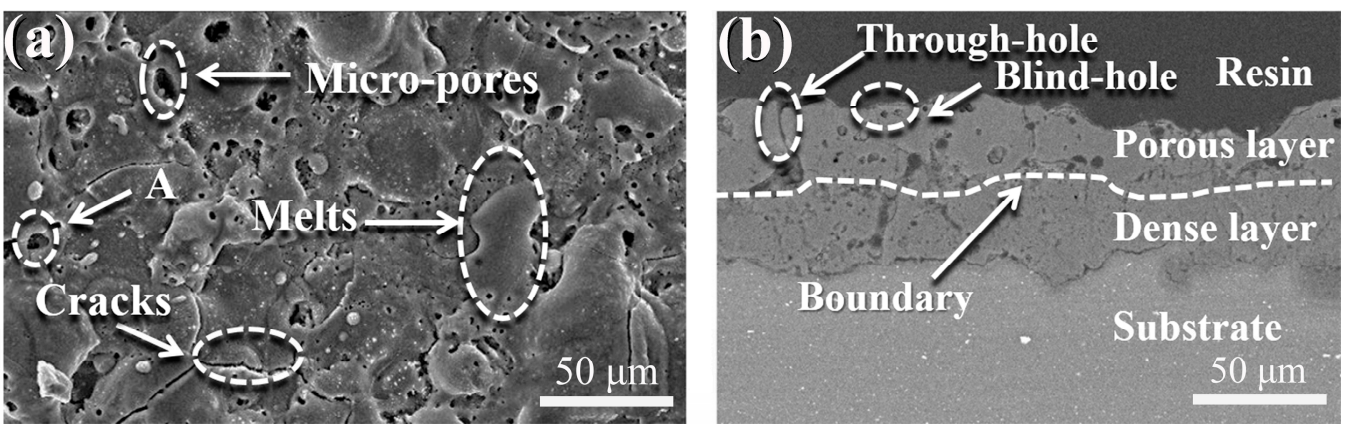

Figure 1. (a) Surface and (b) cross-sectional morphologies of micro-arc oxidation (MAO) coating.

The XRD results showed that the main phases of the coating were $\mathrm{MgO}, \mathrm{Mg}, \mathrm{Mg}_{2} \mathrm{SiO}_{4}, \mathrm{Mg}_{3}\left(\mathrm{PO}_{4}\right)_{2}$, and $\mathrm{CaCO}_{3}$ (Figure 2). Ca, $\mathrm{P}$, and $\mathrm{Si}$ from the electrolyte were found in these phases, indicating that the electrolyte contributed to the formation of the bio-ceramic coating by reacting with the sample. It is believed that the difference in thermal expansion coefficients between the phases resulted in the micro-cracks in the coating [48]. The surface roughness and contact angle between the coating and water are shown in Figure 3. Micro-pores, melts, and cracks resulted in a rough coating surface. The roughness $(R a)$ was about $3.765 \mu \mathrm{m}$ (Figure 3a), which favors the spreading of water molecules [15]. The wetting angle was about $0^{\circ}$ (Figure $3 b$ ), which is suitable for cells to adhere to and grow on $[19,49]$.

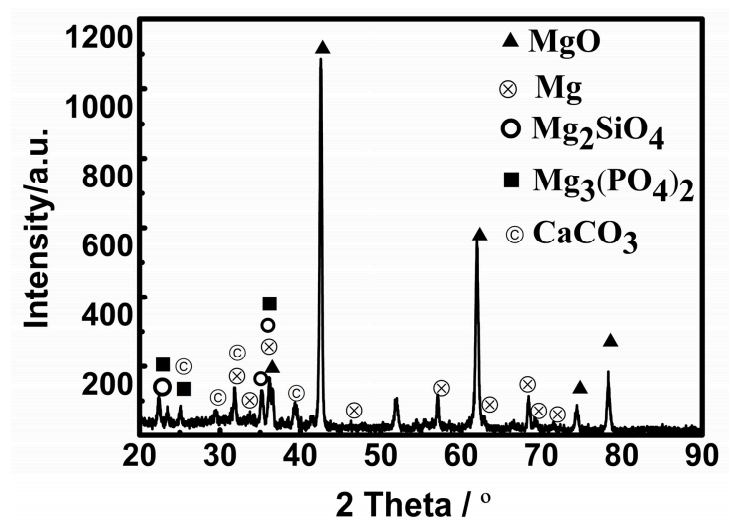

Figure 2. X-ray diffraction (XRD) pattern of the MAO coating.

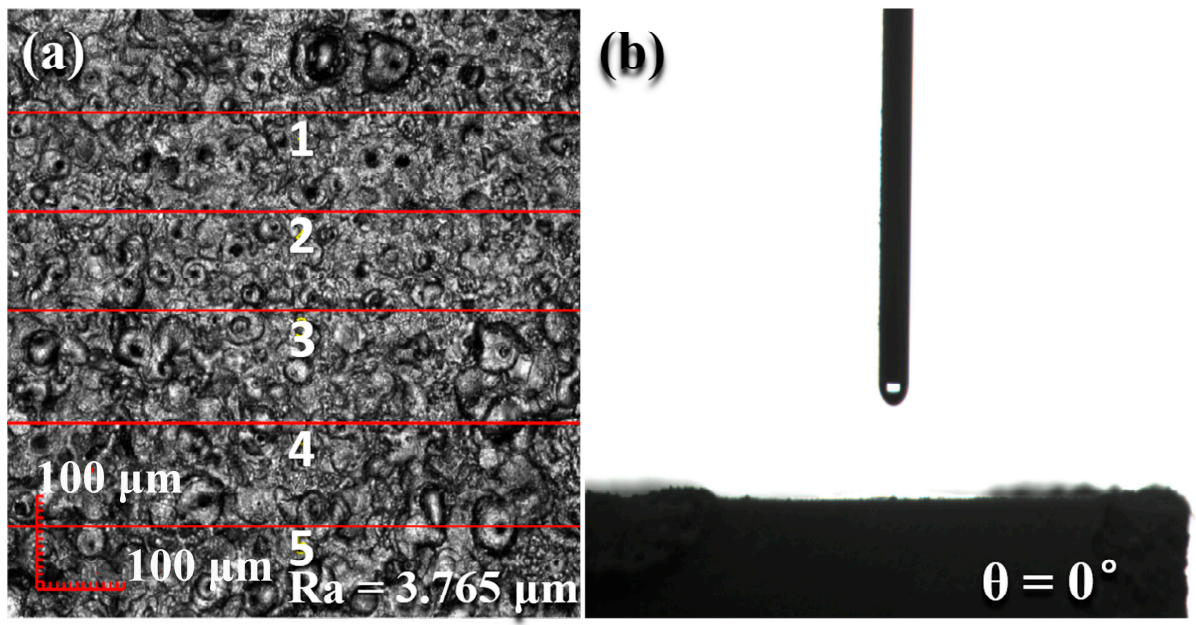

Figure 3. (a) Surface roughness of the MAO coating and (b) water contact angle of the MAO coating. 


\subsection{Changes in $p H$ Values and Weight Loss Rates of the Samples}

The changes in $\mathrm{pH}$ values of SBF and weight loss rate with the immersion time are shown in Figures 4 and 5, respectively. It is obvious that the $\mathrm{pH}$ values of SBF for the uncoated sample were much higher than those for the coated ones (Figure 4). During the first 3 days, the $\mathrm{pH}$ value of the uncoated sample increased sharply. At the 4 th day, the $\mathrm{pH}$ value decreased to about 8.5 . Then, the $\mathrm{pH}$ value rose slowly and tended to become steady gradually. Such changes can be explained by the phenomena observed in the experiment. At the beginning of the immersion experiment, there were many bubbles on the surface of the magnesium alloy. The reasons for this phenomenon [50] can be illustrated by Equations (2)-(4):

$$
\begin{gathered}
\mathrm{Mg} \rightarrow \mathrm{Mg}^{2+}+2 \mathrm{e}^{-} \\
2 \mathrm{H}_{2} \mathrm{O}+2 \mathrm{e}^{-} \rightarrow 2 \mathrm{OH}^{-}+\mathrm{H}_{2} \\
\mathrm{Mg}^{2+}+2 \mathrm{OH}^{-} \rightarrow \mathrm{Mg}(\mathrm{OH})_{2}
\end{gathered}
$$

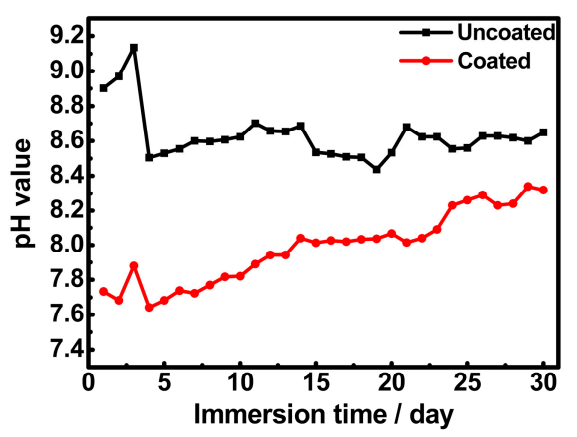

Figure 4. Changes in the $\mathrm{pH}$ values of the simulated blood fluids (SBFs) immersed with different samples over time.

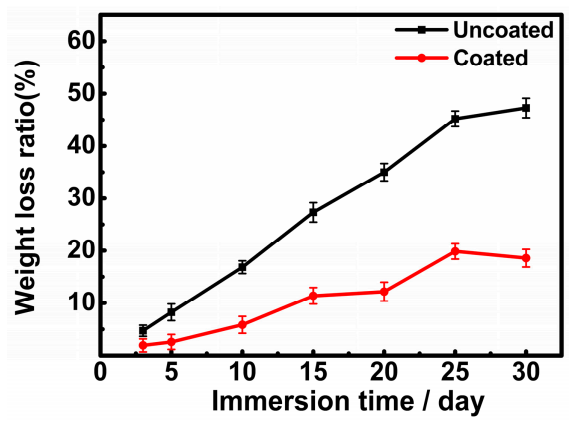

Figure 5. Changes in weight loss rate of the samples over time.

The uncoated sample corroded rapidly in the early stage of the immersion test, releasing many electrons into the solution (Equation (2)). More and more $\mathrm{OH}^{-}$ions were produced by the reaction shown in Equation (3), leading to a fast increase of the $\mathrm{pH}$ value. However, $\mathrm{OH}^{-}$and $\mathrm{Mg}^{2+}$ ions were consumed by the forming $\mathrm{Mg}(\mathrm{OH})_{2}$ (Equation (4)). Then, the reactions in the solution gradually reached equilibrium, and the $\mathrm{pH}$ value became relatively steady. From Figure 5, it can be seen that the weight loss of the uncoated sample increased remarkably and then slowed down in the late stage (after the 25th day) because of the deposition of corrosion products. The degradation of the uncoated sample was inhibited.

Compared with the uncoated samples, the $\mathrm{pH}$ value of SBF for the coated samples maintained a low level. Since the MAO coating decomposed with time, the substrate was exposed gradually to $\mathrm{SBF}$, which led to the increase of the $\mathrm{pH}$ value. During the immersion test, the weight loss rate of the coated sample was much lower than that of the uncoated one, which is consistent with the findings in reference [19]. The weight loss of the coated samples began to slow down after the 15th day (Figure 5). This indicates that the MAO coating could significantly improve the corrosion resistance of ZK60 alloy. 


\subsection{Morphology and Phase Composition of Corroded Samples}

Figure 6a-d display the variations of the morphologies of the uncoated samples immersed in SBF for different amounts of time. In the early stage of the immersion test, the surface of the sample was covered with some network structure formed by the crossing of needle-like products (Figure 6a,b). After 20 days, some white flocculent products deposited on the network structure and the network structure gradually disappeared (Figure $6 c, d$ ). According to the XRD results (Figure 7a), the network structure was composed of $\mathrm{Mg}(\mathrm{OH})_{2}$ and the flocculent product was Ca-P compound. The main phases of the uncoated sample in the early stage were $\mathrm{Mg}(\mathrm{OH})_{2}$ and $\mathrm{Mg}$, while few Ca-P compounds could be detected. In the late stage, the peak of $\mathrm{Mg}(\mathrm{OH})_{2}$ became weak, but the peak intensity of the Ca-P compound became stronger due to increased deposition of the Ca-P compound.
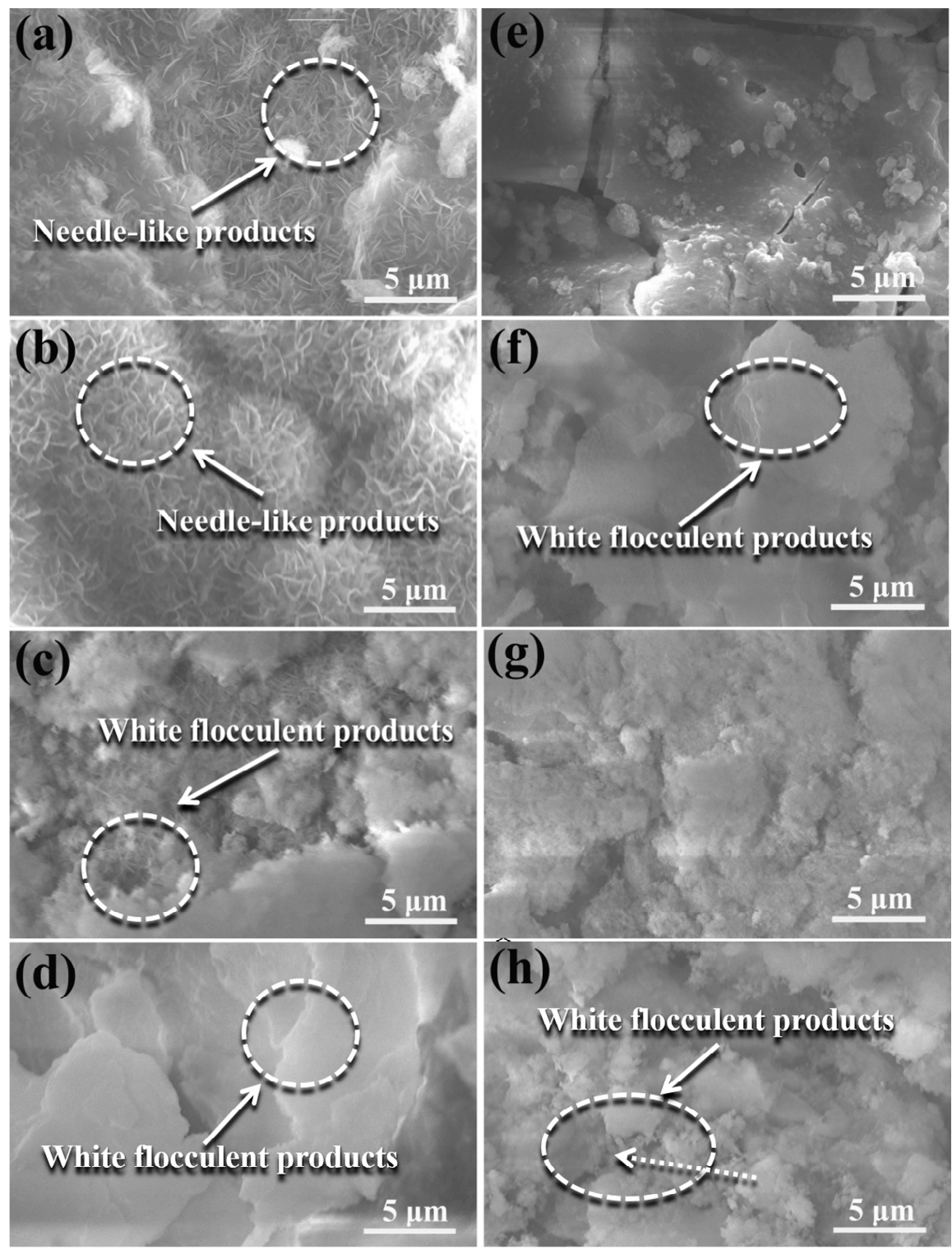

Figure 6. Morphologies of the uncoated and coated samples after immersion for 30 days: (a) 5 days, (b) 10 days, (c) 20 days, and (d) 30 days for uncoated sample, and (e) 5 days, (f) 10 days, (g) 20 days, and (h) 30 days for MAO coated sample, respectively. 

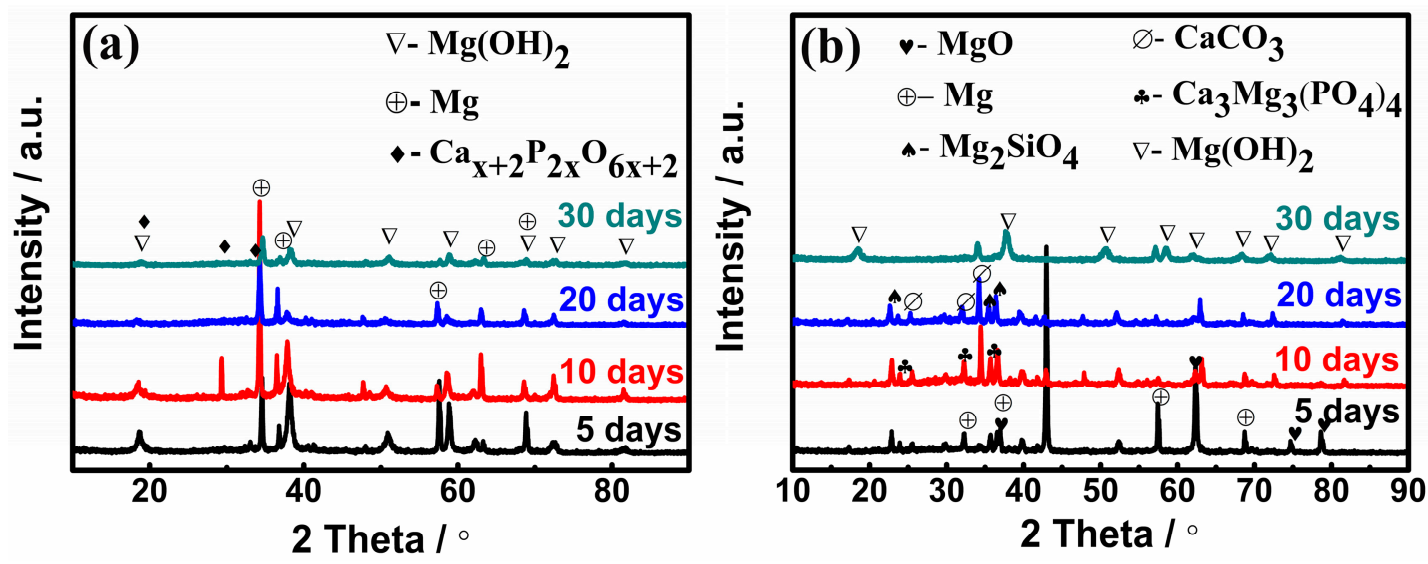

Figure 7. XRD patterns of (a) the uncoated and (b) the MAO coated samples after immersion for 30 days.

Figure 6e-h show the variations of morphologies of the coated samples immersed in SBF for different amounts of time. The micro-pores and cracks on the coating surface were gradually covered by the white flocculent products over time, and more white products could be seen around the cracks. According to Figure $7 \mathrm{~b}$, the surface of the coated sample mainly consisted of $\mathrm{MgO}, \mathrm{Mg}, \mathrm{Mg}_{2} \mathrm{SiO}_{4}$, $\mathrm{CaCO}_{3}$, and $\mathrm{Ca}_{3} \mathrm{Mg}_{3}\left(\mathrm{PO}_{4}\right)_{4} \cdot \mathrm{MgO}, \mathrm{Mg}, \mathrm{Mg}_{2} \mathrm{SiO}_{4}$, and $\mathrm{CaCO}_{3}$ are all from the coating (Figure 2), while $\mathrm{Ca}_{3} \mathrm{Mg}_{3}\left(\mathrm{PO}_{4}\right)_{4}$ is the corrosion product.

\subsection{FTIR Spectra of Corrosion Products}

FTIR results of uncoated samples and coated samples under different immersion times are shown in Figure 8. For uncoated samples, the $\mathrm{C}-\mathrm{O}$ and $\mathrm{C}=\mathrm{O}$ stretching vibration mode occurring at $1055 \mathrm{~cm}^{-1}$ and $1647 \mathrm{~cm}^{-1}$ are ascribed to the carbon ionic groups of the SBF solution, which might diffuse into the corrosion products in the form of ions. Furthermore, the $\mathrm{O}-\mathrm{H}$ bands vibration mode occurred at $3437 \mathrm{~cm}^{-1}$. Obviously, the absorption peaks of $\mathrm{O}-\mathrm{H}$ became wider with immersion time, demonstrating that the association between functional groups was enhanced. It could also be found that $\mathrm{O}-\mathrm{H}$ sharp stretching vibration mode occurred at $399 \mathrm{~cm}^{-1}$, which could be attributed to the dissociative $\mathrm{O}-\mathrm{H}$ [51]. According to the FTIR spectrum results, the content of $\mathrm{Mg}(\mathrm{OH})_{2}$ increased with immersion time.
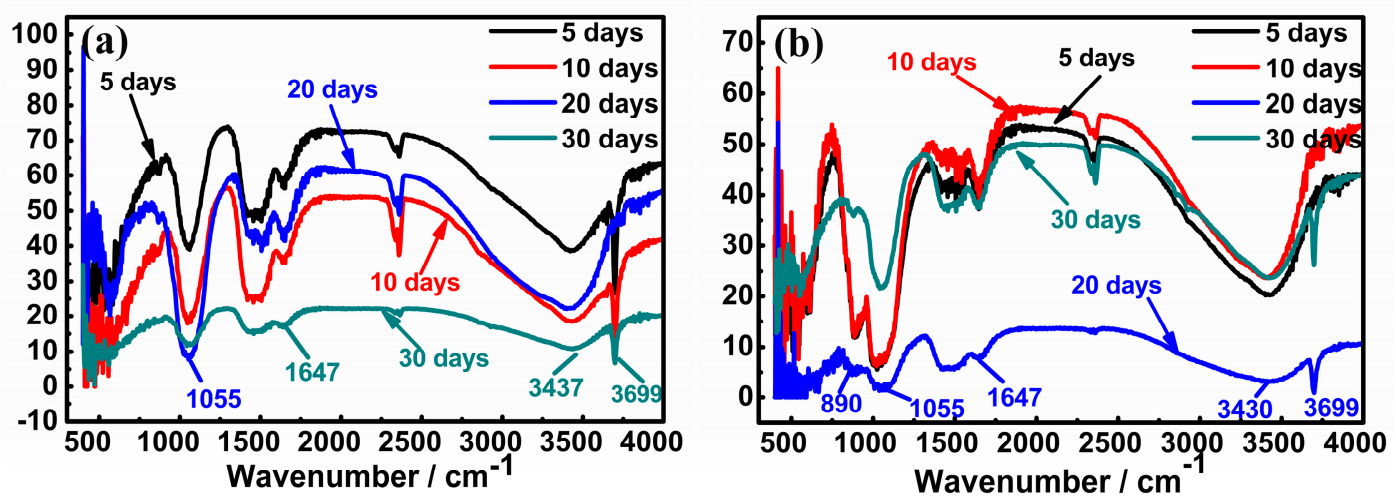

Figure 8. Fourier transform infrared spectroscopy (FTIR) of corrosion products on samples: (a) uncoated (b) MAO coated.

By contrast, according to the FTIR spectra of coated samples in Figure $8 \mathrm{~b}$, the P-O stretching vibration mode occurred at $890 \mathrm{~cm}^{-1}$, which also confirmed the presence of $\mathrm{Ca}_{3} \mathrm{Mg}_{3}\left(\mathrm{PO}_{4}\right)_{4}$ during long-term immersion in SBF. The intensities of $\mathrm{P}-\mathrm{O}$ peaks declined over immersion time, illustrating a gradual degradation of $\mathrm{Ca}_{3} \mathrm{Mg}_{3}\left(\mathrm{PO}_{4}\right)_{4}$ as the peak of $\mathrm{P}-\mathrm{O}$ was hardly found after immersion for 
30 days. This phenomenon demonstrates an MAO coating with good degradability. The bands at $1055 \mathrm{~cm}^{-1}$ and $1647 \mathrm{~cm}^{-1}$ correspond to $\mathrm{C}-\mathrm{O}$ and $\mathrm{C}=\mathrm{O}$ stretching vibration modes. They are produced from $\mathrm{CaCO}_{3}$ in the $\mathrm{MAO}$ coating. After 30 days of soaking, the widths of the two peaks became broad and the peak value decreased, proving the amount of $\mathrm{CaCO}_{3}$ had declined, which indicates that MAO coating underwent progressive decomposition over time [52].

\subsection{Electrochemical Impedance Spectroscopy}

The Nyquist plots of both uncoated and coated samples after immersing in SBF for various amounts of time are presented in Figure 9. Equivalent circuits for fitting the uncoated and coated samples are shown in Figure 10. The non-ideal capacitive behavior of the coating is taken into account by using constant phase element (CPE) instead of capacitances in the model $[53,54]$. In the equivalent circuits, $R_{\mathrm{soln}}$ is the SBF solution resistance, $R_{\mathrm{cp}}$ is the corrosion product resistance with constant phase element $C P E_{\mathrm{cp}}, R_{\mathrm{coat}}$ is the coating resistance paralleled with constant phase element $C P E_{\mathrm{coat}}$, and $R_{\mathrm{ct}}$ is the reaction resistance paralleled with constant phase element $C P E_{\mathrm{ct}}$. The use of a $C P E$ was necessary due to the distribution of relaxation times resulting from heterogeneities at the electrode surface [55]. The impedance of the CPE is given by Equation (5) [56]:

$$
Z_{C P E}=\frac{1}{Q}(j \omega)^{-n}
$$
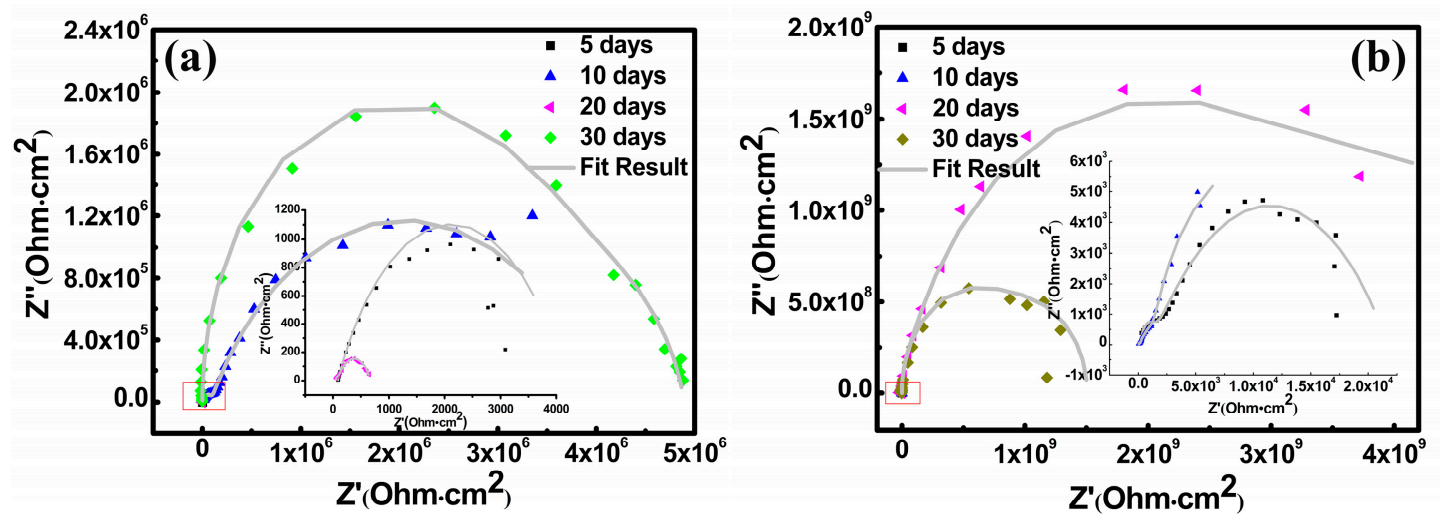

Figure 9. Nyquist plots of (a) the uncoated and (b) the MAO coated samples.

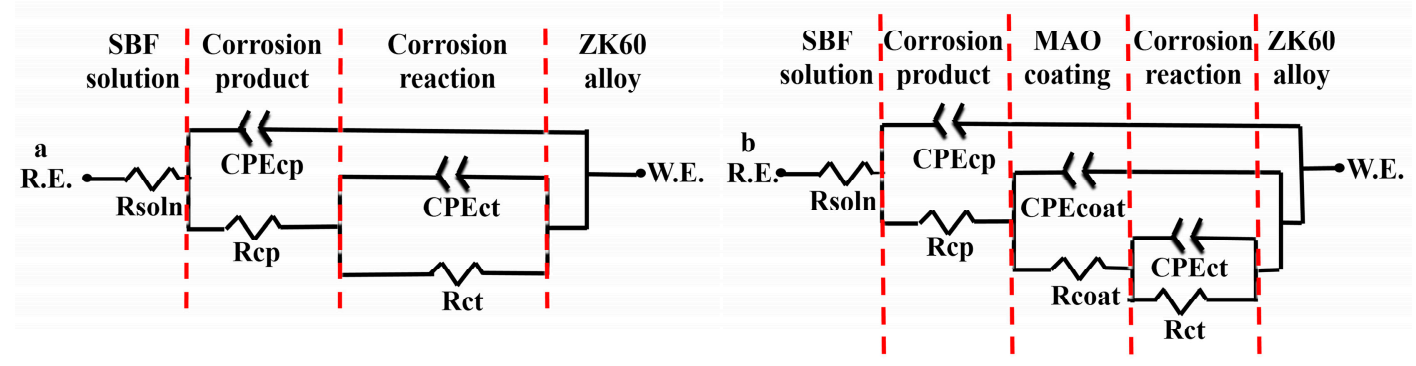

Figure 10. Equivalent circuits for fitting the impedance data of (a) the uncoated and (b) the MAO coated samples in SBF. CPE: constant phase element.

The fitting EIS results are listed in Table 3. Figure 11 shows the open circuit potentials for the uncoated and the coated samples after immersion for 30 days. The global impedances of the coated samples were much higher than those of the uncoated ones (Figure 9). This suggests that the MAO coating could effectively inhibit the degradation of the substrate. For the uncoated samples, the $R_{\mathrm{ct}}$ value increased from day 5 to day 10 and from day 20 to day 30 (Table 3), indicating that the degradation and deposition were active simultaneously. For the coated samples, the $R_{\mathrm{ct}}$ value 
increased from day 5 to day 20, and then decreased. The increase of the $R_{\mathrm{ct}}$ value for the coated samples indicates that the deposition of the corrosion product layer inhibited the penetration of the SBF through the coating. With the continuous reaction between the solution and the coating, the thickness of the coating decreased with the increase of the corrosion product layer. So, the $R_{\text {coat }}$ decreased. However, the weight loss rate of the coated sample increased gradually (Figure 5), suggesting that the degradation of the coating was faster than the deposition of corrosion product. After immersion for 30 days, a large part of the coating dissolved in the solution and the substrate was exposed. Thus, the $R_{\mathrm{ct}}$ value decreased again.

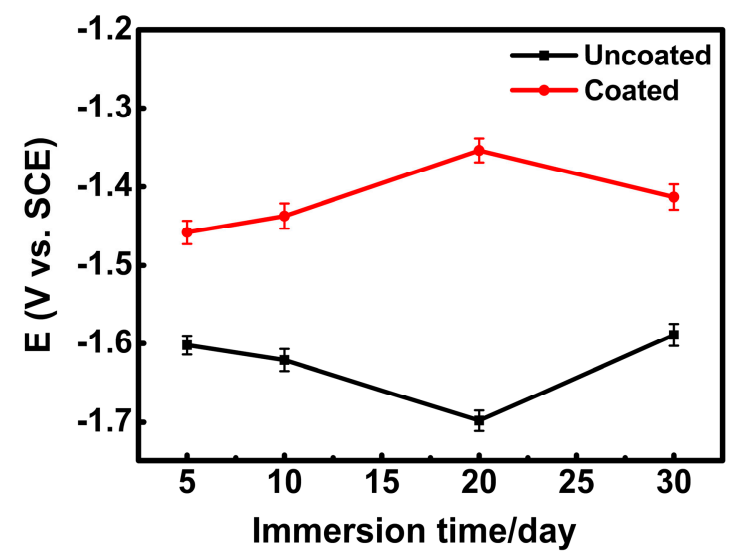

Figure 11. The evolution of open circuit potentials for the uncoated and the coated samples after immersion for 30 days. 
Table 3. Electrochemical parameters of the uncoated and coated samples after immersion in SBF for various amounts of time.

\begin{tabular}{|c|c|c|c|c|c|c|c|c|c|c|c|}
\hline Sample & $\begin{array}{l}\text { Immersion } \\
\text { Time (Days) }\end{array}$ & $\underset{\left(\Omega \cdot \mathrm{cm}^{2}\right)}{R_{\text {soln }}}$ & $Q_{\mathrm{cp}}\left(\Omega^{-1} \cdot \mathrm{cm}^{-2} \mathrm{~s}^{n}\right)$ & $n$ & $R_{\mathrm{cp}}\left(\Omega \cdot \mathrm{cm}^{2}\right)$ & $Q_{\text {coat }}\left(\Omega^{-1} \cdot \mathrm{cm}^{-2} \mathrm{~s}^{n}\right)$ & $n$ & $\begin{array}{c}R_{\text {coat }} \\
\left(\Omega \cdot \mathrm{cm}^{2}\right)\end{array}$ & $Q_{\mathrm{ct}}\left(\Omega^{-1} \cdot \mathrm{cm}^{-2} \mathrm{~s}^{n}\right)$ & $n$ & $R_{\mathrm{ct}}\left(\Omega \cdot \mathrm{cm}^{2}\right)$ \\
\hline \multirow{4}{*}{ Uncoated } & 5 & 36 & $2.10 \times 10^{-4}$ & 0.89 & 86.73 & - & - & - & $3.65 \times 10^{-6}$ & 0.86 & 2056 \\
\hline & 10 & 52 & $1.33 \times 10^{-5}$ & 0.91 & 122.4 & - & - & - & $3.59 \times 10^{-6}$ & 0.80 & 3454 \\
\hline & 20 & 43 & $8.57 \times 10^{-4}$ & 0.83 & 46.47 & - & - & - & $4.18 \times 10^{-5}$ & 0.88 & 579.3 \\
\hline & 30 & 56 & $2.36 \times 10^{-6}$ & 0.84 & 1206 & - & - & - & $1.50 \times 10^{-7}$ & 0.95 & 4496 \\
\hline \multirow{4}{*}{ MAO Coated } & 5 & 58 & $5.12 \times 10^{-6}$ & 0.92 & 2124 & $3.88 \times 10^{-7}$ & 0.85 & 2081 & $4.43 \times 10^{-6}$ & 0.80 & $2.78 \times 10^{4}$ \\
\hline & 10 & 42 & $2.30 \times 10^{-6}$ & 0.86 & 8205 & $1.82 \times 10^{-6}$ & 0.89 & 272.3 & $2.75 \times 10^{-6}$ & 0.82 & $4.03 \times 10^{4}$ \\
\hline & 20 & 47 & $3.52 \times 10^{-7}$ & 0.87 & $1.08 \times 10^{4}$ & $4.18 \times 10^{-4}$ & 0.90 & 0.02 & $2.35 \times 10^{-7}$ & 0.89 & $6.73 \times 10^{4}$ \\
\hline & 30 & 75 & $4.65 \times 10^{-6}$ & 0.81 & 6587 & $3.25 \times 10^{-4}$ & 0.82 & 0.53 & $8.69 \times 10^{-6}$ & 0.81 & $1.39 \times 10^{4}$ \\
\hline
\end{tabular}




\section{Discussion}

\subsection{Degradation Mechanism of Uncoated ZK60 Alloy}

Li et al. [57] suggested a biocorrosion model that can be used to describe the corrosion process of $\mathrm{Mg}$ alloys. According to this concept, the degradation model of ZK60 Mg alloy in SBF is proposed as shown in Figure 12a. Xu et al. [18] indicated that uniform corrosion and localized corrosion are the two mechanisms during the degradation process. In the early stage of immersion, $\mathrm{Mg}$ encounters an anodic dissolution (Equation (2)), accompanied by the release of $\mathrm{H}_{2}$ and the $\mathrm{Mg}(\mathrm{OH})_{2}$ film formed on $\mathrm{Mg}$ alloy (Equations (3) and (4)). This is a uniform corrosion process, as shown in Figure 12a. In SBF, localized corrosion is mostly due to the penetration of $\mathrm{Cl}^{-}$ions from the solution. Lederer et al. [58] reveals that $\mathrm{Cl}^{-}$ions can not only damage the $\mathrm{Mg}(\mathrm{OH})_{2}$ film, but also corrode the $\mathrm{Mg}$ alloy. The reactions are suggested as follows:

$$
\begin{gathered}
\mathrm{Mg}(\mathrm{OH})_{2}+2 \mathrm{Cl}^{-} \rightarrow \mathrm{MgCl}_{2}+2 \mathrm{OH}^{-} \\
\mathrm{Mg}^{2+}+2 \mathrm{Cl}^{-} \rightarrow \mathrm{MgCl}_{2}
\end{gathered}
$$
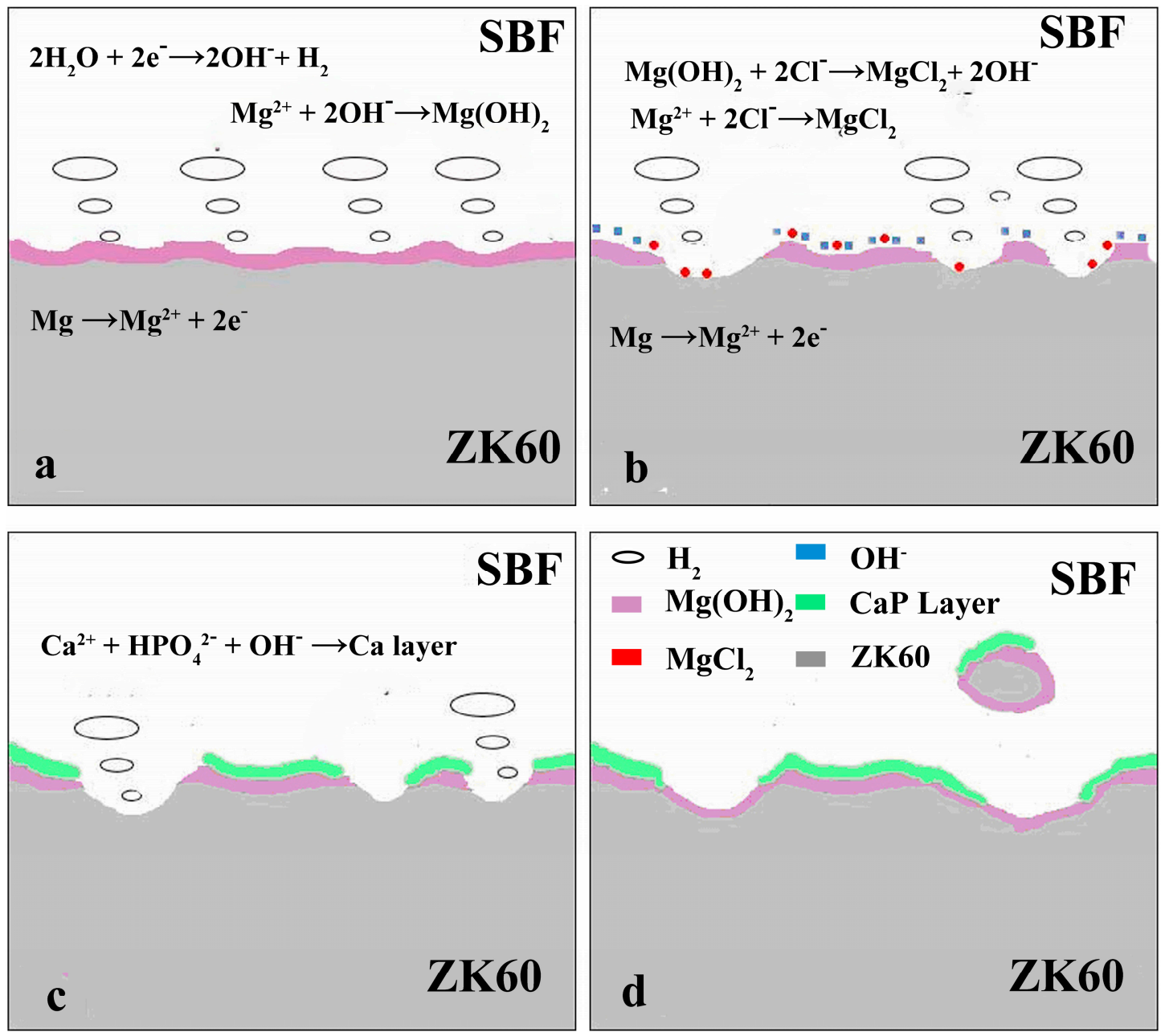

Figure 12. Degradation models of the uncoated samples upon immersion in the SBF. (a) uniform corrosion stage, (b) localized corrosion stage, (c) Ca-P formation stage, and (d) local decomposition stage. 
The $\mathrm{Cl}^{-}$in SBF reacts with $\mathrm{Mg}(\mathrm{OH})_{2}$, and these reactions generate $\mathrm{MgCl}_{2}$ and $\mathrm{OH}^{-}$. Hence, the surface of the alloy is surrounded by a large amount of $\mathrm{OH}^{-}$(Figure 12b) [59]. Then, $\mathrm{Ca}^{2+}$ and $\mathrm{HPO}_{4}{ }^{2-}$ in SBF react with $\mathrm{OH}^{-}$(Figure 12c), as indicated by Equation (8) [60]:

$$
\mathrm{Ca}^{2+}+\mathrm{HPO}_{4}{ }^{2-}+\mathrm{OH}^{-} \rightarrow \mathrm{Ca}-\mathrm{P} \text { layer }+\mathrm{H}_{2} \mathrm{O}
$$

As the uniform corrosion and the localized corrosion proceed, part of the sample decomposes into free particles in the solution (Figure 12d). In this way, $\mathrm{Mg}$ alloy is covered by corrosion products and exposed to the solution again and again, which results in unsteady EIS data (Table 3).

Zhang et al. [61] reported that the corrosion of $\mathrm{Mg}$ alloy is closely associated with the corrosion of alpha phase. Moreover, the intermetallic compound beta phase between magnesium and alloying elements itself is not readily corroded as a function of the cathode in galvanic corrosion. When the content of beta phase is high and its distribution is continuous, uniform, and fine, grains of alpha phase are almost entirely separated by beta phase, so the corrosion can hardly pass from one grain to another. In this way, beta phase acts as a barrier against corrosion. When beta phase is of lower content and its distribution is not continuous, corrosion diffuses easily. In this condition, the beta phase accelerates the galvanic corrosion. Beta phase $\left(\mathrm{Mg}_{7} \mathrm{Zn}_{3}\right)$ is unable to distribute continuously in ZK60 because of the low solid solubility of their alloying elements in magnesium and the low content of Al. So, the corrosion process is accelerated, resulting in a decrease of corrosion resistance.

\subsection{Degradation Mechanism of the Coated ZK60 Alloy}

Gu et al. [19,35] suggested a degradation model of the MAO coating in SBF (Figure 13). Generally, the MAO coating consists of a porous layer and a dense layer. In the early stage of immersion, only the $\mathrm{MgO}$ from the coating reacts with the solution. The reaction is shown below:

$$
\mathrm{MgO}+\mathrm{H}_{2} \rightarrow \mathrm{Mg}(\mathrm{OH})_{2}
$$

A certain amount of $\mathrm{Mg}(\mathrm{OH})_{2}$ transforms into $\mathrm{MgCl}_{2}$ (Equation (6)), leaving the $\mathrm{OH}^{-}$on the surface (Figure 13a). And then a Ca-P product layer forms since the $\mathrm{OH}^{-}$subsequently reacts with the other compounds and ions [62]. The following is the possible reaction:

$$
3 \mathrm{Ca}^{2+}+\mathrm{Mg}_{3}\left(\mathrm{PO}_{4}\right)_{2}+2 \mathrm{HPO}_{4}{ }^{2-}+2 \mathrm{OH}^{-} \rightarrow \mathrm{Ca}_{3} \mathrm{Mg}_{3}\left(\mathrm{PO}_{4}\right)_{4}+2 \mathrm{H}_{2} \mathrm{O} .
$$

As the immersion test continues, SBF solution penetrates the loose layer, diffusing into and enlarging the micro-pores of the layer, thereby permitting the SBF's penetration into the dense layer and even the substrate alloy (Figure 13b). Once the solution contacts the substrate, $\mathrm{Mg}$ reacts with the solution and produces $\mathrm{Mg}(\mathrm{OH})_{2}$ together with $\mathrm{H}_{2}$ (Equations (2)-(4)). When all the pores are penetrated, rapid degradation takes place (Figure 13c) and the coating is therefore dissolved (Figure 13d).

Therefore, a thick dense layer can inhibit the penetration of the SBF. Meanwhile, the smaller the pores, the more slowly they enlarge. Under such a condition (i.e., a thick dense layer with small pores), the Ca-P product layer covers the surface of the coating, which would inhibit the coating's degradation. If the coating degrades as shown in Figure 13d, a large amount of $\mathrm{Mg}(\mathrm{OH})_{2}$ would be gained. Without the coating composition, $\mathrm{Ca}_{3} \mathrm{Mg}_{3}\left(\mathrm{PO}_{4}\right)_{4}$ cannot be produced. The reactions in SBF would change into the ones in Figure 12a, then the degradation model of the coated samples in SBF would be the same as the uncoated samples. 

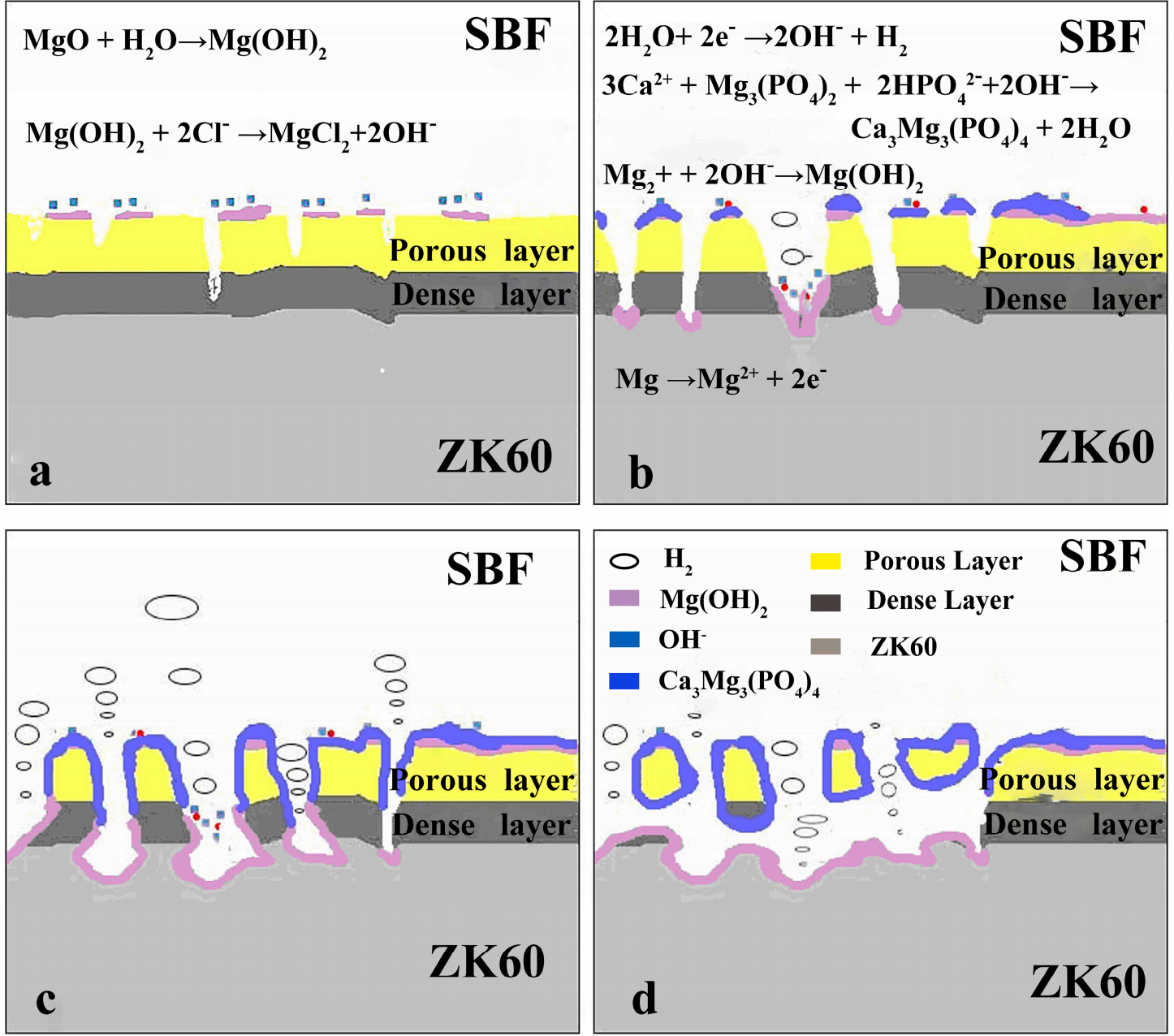

Figure 13. Degradation models of the MAO coated samples upon immersion in the SBF: (a) surface corrosion stage, (b) micro-pore enlargement stage, (c) coating degradation stage, and (d) coating decomposition stage.

\section{Conclusions}

Bio-ceramic coatings were fabricated on ZK60 Mg alloy through micro-arc oxidation, and both coated and uncoated samples were immersed in SBF for 30 days to study their degradation behavior. The main conclusions were drawn as follows:

(1) A porous coating prepared by $\mathrm{MAO}$ mainly consisted of $\mathrm{MgO}, \mathrm{Mg}_{2} \mathrm{SiO}_{4}, \mathrm{Mg}_{3}\left(\mathrm{PO}_{4}\right)_{2}$, and $\mathrm{CaCO}_{3}$ with a dense inner layer and a porous outer layer. The rough surface $(R a=3.765 \mu \mathrm{m})$ of the coating was very hydrophilic, which favored cells' adherence and growth.

(2) During the immersion period, the $\mathrm{pH}$ value of the SBF solution with coated samples was lower than that of uncoated samples, which indicates the coated samples showed a much lower rate of degradation. The second phase $\mathrm{Mg}_{7} \mathrm{Zn}_{3}$ in $\mathrm{ZK} 60$ led to the micro-couple corrosion between the second phase and the matrix metal, resulting in the decrease of corrosion resistance.

(3) After immersion for 5 days, corrosion product containing Ca and $\mathrm{P}$ was found on both samples, while the deposition was more active on the coated samples. With the decomposition of the coating, the Ca-P compounds disappeared in the late stage. EIS results indicated that the degradation rate of the coated sample decreased with the immersion time, and in the equivalent circuits the $R_{\mathrm{ct}}$ value increased accordingly.

(4) Degradation models for the uncoated and coated samples in the SBF are proposed, which explain the degradation process and corrosion mechanism for the samples in different periods. 
The corrosion product of $\mathrm{Ca}_{3} \mathrm{Mg}_{3}\left(\mathrm{PO}_{4}\right)_{4}$ can inhibit the coating from degrading, and the degradation rate of MAO coating depends on the thickness of the dense layer and the pore size.

Author Contributions: Z.-X.W. and L.X. conceived and designed the experiments; G.-Q.C. and L.X. performed the experiments; Z.-X.W. and S.L. analyzed the data; Z.-X.W., L.-Y.C., and S.L. wrote the paper.

Funding: This research was funded by Postgraduate Research \& Practice Innovation Program of Jiangsu Province KYCX18_2317.

Acknowledgments: The authors would like to acknowledge a financial support provided by Postgraduate Research \& Practice Innovation Program of Jiangsu Province. The authors also would like to acknowledge Instrumental Analysis Center of Jiangsu University of Science and Technology for providing technology support.

Conflicts of Interest: The authors declare no conflict of interest.

\section{References}

1. Bian, D.; Zhou, W.; Deng, J.; Liu, Y.; Li, W.; Chu, X.; Xiu, P.; Cai, H.; Kou, Y.; Jiang, B.; et al. Development of magnesium-based biodegradable metals with dietary trace element germanium as orthopaedic implant applications. Acta Biomater. 2017, 64, 421-436. [CrossRef] [PubMed]

2. Zheng, Y.; Lai, L.; Liu, W.; Jiang, H.; Wang, X. Recent advances in biomedical applications of fluorescent gold nanoclusters. Adv. Colloid Interface Sci. 2017, 242, 1-16. [CrossRef] [PubMed]

3. Gao, Y.; Yerokhin, A.; Matthews, A. Mechanical behaviour of cp-magnesium with duplex hydroxyapatite and PEO coatings. Mater. Sci. Eng. C 2015, 49, 190-200. [CrossRef] [PubMed]

4. Xu, L.; Shi, X.; Ouyang, C.; Liu, W. In vitro apatite formation, protein adsorption and initial osteoblast responses on titanium surface enriched with magnesium. Rare Met. Mater. Eng. 2017, 46, 1512-1517.

5. Ehtemam-Haghighi, S.; Cao, G.; Zhang, L.-C. Nanoindentation study of mechanical properties of Ti based alloys with Fe and Ta additions. J. Alloys Compd. 2017, 692, 892-897. [CrossRef]

6. Staiger, M.P.; Pietak, A.M.; Huadmai, J.; Dias, G. Magnesium and its alloys as orthopedic biomaterials: A review. Biomaterials 2006, 27, 1728-1734. [CrossRef] [PubMed]

7. Bakhsheshi-Rad, H.R.; Hamzah, E.; Daroonparvar, M.; Abdul Kadir, M.R.; Kasiri-Asgarani, M.; Staiger, M.P. Enhancement of corrosion resistance and mechanical properties of Mg-1.2Ca-2Bi via a hybrid silicon-biopolymer coating system. Surf. Coat. Technol. 2016, 301, 133-139. [CrossRef]

8. Liu, L.H.; Yang, C.; Wang, F.; Qu, S.G.; Li, X.Q.; Zhang, W.W.; Li, Y.Y.; Zhang, L.C. Ultrafine grained Ti-based composites with ultrahigh strength and ductility achieved by equiaxing microstructure. Mater. Des. 2015, 79, 1-5. [CrossRef]

9. Calin, M.; Zhang, L.C.; Eckert, J. Tailoring of microstructure and mechanical properties of a Ti-based bulk metallic glass-forming alloy. Scr. Mater. 2007, 57, 1101-1104. [CrossRef]

10. Bakhsheshi-Rad, H.R.; Hamzah, E.; Ismail, A.F.; Aziz, M.; Daroonparvar, M.; Saebnoori, E.; Chami, A. In vitro degradation behavior, antibacterial activity and cytotoxicity of $\mathrm{TiO}_{2}-\mathrm{MAO} / \mathrm{ZnHA}$ composite coating on Mg alloy for orthopedic implants. Surf. Coat. Technol. 2018, 334, 450-460. [CrossRef]

11. Hornberger, H.; Virtanen, S.; Boccaccini, A.R. Biomedical coatings on magnesium alloys-A review. Acta Biomater. 2012, 8, 2442-2455. [CrossRef] [PubMed]

12. Liu, J.; Willför, S.; $\mathrm{Xu}, \mathrm{C}$. A review of bioactive plant polysaccharides: Biological activities, functionalization, and biomedical applications. Bioact. Carbohydr. Diet. Fibre 2015, 5, 31-61. [CrossRef]

13. Li, X.; Liu, X.; Wu, S.; Yeung, K.W.K.; Zheng, Y.; Chu, P.K. Design of magnesium alloys with controllable degradation for biomedical implants: From bulk to surface. Acta Biomater. 2016, 45, 2-30. [CrossRef] [PubMed]

14. Witte, F. Reprint of: The history of biodegradable magnesium implants: A review. Acta Biomater. 2015, 23, S28-S40. [CrossRef] [PubMed]

15. Jiang, H.; Wang, J.; Chen, M.; Liu, D. Biological activity evaluation of magnesium fluoride coated Mg-Zn-Zr alloy in vivo. Mater. Sci. Eng. C 2017, 75, 1068-1074. [CrossRef] [PubMed]

16. Li, L.; Gao, J.; Wang, Y. Evaluation of cyto-toxicity and corrosion behavior of alkali-heat-treated magnesium in simulated body fluid. Surf. Coat. Technol. 2004, 185, 92-98. [CrossRef] 
17. Guan, R.; Cipriano, A.F.; Zhao, Z.; Lock, J.; Tie, D.; Zhao, T.; Cui, T.; Liu, H. Development and evaluation of a magnesium-zinc-strontium alloy for biomedical applications-Alloy processing, microstructure, mechanical properties, and biodegradation. Mater. Sci. Eng. C 2013, 33, 3661-3669. [CrossRef] [PubMed]

18. Zhao, X.; Shi, L.; Xu, J. Mg-Zn-Y alloys with long-period stacking ordered structure: In vitro assessments of biodegradation behavior. Mater. Sci. Eng. C 2013, 33, 3627-3637. [CrossRef] [PubMed]

19. Gu, Y.; Bandopadhyay, S.; Chen, C.; Ning, C.; Guo, Y. Long-term corrosion inhibition mechanism of microarc oxidation coated AZ31 Mg alloys for biomedical applications. Mater. Des. 2013, 46, 66-75. [CrossRef]

20. Shizhao, S.; Yanze, B.; Minfang, C.; Debao, L.; Chen, Y.; Yan, H. Degradation mechanism of the biomedical $\mathrm{Mg}-3 \mathrm{Zn}-0.5 \mathrm{Zr}$ alloy in a simulated physiological environment containing different anions. Rare Met. Mater. Eng. 2016, 45, 2827-2834. [CrossRef]

21. McEntire, B.J.; Bal, B.S.; Rahaman, M.N.; Chevalier, J.; Pezzotti, G. Ceramics and ceramic coatings in orthopaedics. J. Eur. Ceram. Soc. 2015, 35, 4327-4369. [CrossRef]

22. Wang, L.; Xie, L.; Lv, Y.; Zhang, L.-C.; Chen, L.; Meng, Q.; Qu, J.; Zhang, D.; Lu, W. Microstructure evolution and superelastic behavior in Ti-35Nb-2Ta-3Zr alloy processed by friction stir processing. Acta Mater. 2017, 131, 499-510. [CrossRef]

23. Wang, L.; Xie, L.; Zhang, L.-C.; Chen, L.; Ding, Z.; Lv, Y.; Zhang, W.; Lu, W.; Zhang, D. Microstructure evolution and superelasticity of layer-like $\mathrm{NiTiNb}$ porous metal prepared by eutectic reaction. Acta Mater. 2018, 143, 214-226. [CrossRef]

24. Yang, K.; Tan, L. Control of biodegradation of magnesium (Mg) alloys for medical applications. Corros. Prev. Magnes. Alloys 2013, 509-543.

25. Yazici, M.; Gulec, A.E.; Gurbuz, M.; Gencer, Y.; Tarakci, M. Biodegradability and antibacterial properties of MAO coatings formed on $\mathrm{Mg}-\mathrm{Sr}-\mathrm{Ca}$ alloys in an electrolyte containing Ag doped hydroxyapatite. Thin Solid Films 2017, 644, 92-98. [CrossRef]

26. Lei, J.; Shi, C.; Zhou, S.; Gu, Z.; Zhang, L.-C. Enhanced corrosion and wear resistance properties of carbon fiber reinforced Ni-based composite coating by laser cladding. Surf. Coat. Technol. 2018, 334, 274-285. [CrossRef]

27. Chen, L.-Y.; Xu, T.; Lu, S.; Wang, Z.-X.; Chen, S.; Zhang, L.-C. Improved hardness and wear resistance of plasma sprayed nanostructured NiCrBSi coating via short-time heat treatment. Surf. Coat. Technol. 2018, 350, 436-444. [CrossRef]

28. Gray, J.E.; Luan, B. Protective coatings on magnesium and its alloys-A critical review. J. Alloys Compd. 2002, 336, 88-113. [CrossRef]

29. Rokosz, K.; Hryniewicz, T.; Gaiaschi, S.; Chapon, P.; Raaen, S.; Pietrzak, K.; Malorny, W.; Salvador Fernandes, J. Characterization of porous phosphate coatings enriched with magnesium or zinc on CP titanium grade 2 under DC plasma electrolytic oxidation. Metals 2018, 8, 112. [CrossRef]

30. Shao, L.; Li, H.; Jiang, B.; Liu, C.; Gu, X.; Chen, D.; Shao, L.; Li, H.; Jiang, B.; Liu, C.; et al. Comparative study of corrosion behavior of hard anodized and micro-arc oxidation coatings on 7050 aluminum alloy. Metals 2018, 8, 165. [CrossRef]

31. Hakimizad, A.; Raeissi, K.; Santamaria, M.; Asghari, M. Effects of pulse current mode on plasma electrolytic oxidation of $7075 \mathrm{Al}$ in $\mathrm{Na}_{2} \mathrm{WO}_{4}$ containing solution: From unipolar to soft-sparking regime. Electrochim. Acta 2018, 284, 618-629. [CrossRef]

32. Wilke, B.M.; Zhang, L.; Li, W.; Ning, C.; Chen, C.; Gu, Y. Corrosion performance of MAO coatings on AZ31 Mg alloy in simulated body fluid vs. Earle's Balance Salt Solution. Appl. Surf. Sci. 2016, 363, 328-337. [CrossRef]

33. Sankara Narayanan, T.S.N.; Park, I.S.; Lee, M.H. Strategies to improve the corrosion resistance of microarc oxidation (MAO) coated magnesium alloys for degradable implants: Prospects and challenges. Prog. Mater. Sci. 2014, 60, 1-71. [CrossRef]

34. Antunes, R.A.; de Oliveira, M.C.L. Corrosion fatigue of biomedical metallic alloys: Mechanisms and mitigation. Acta Biomater. 2012, 8, 937-962. [CrossRef] [PubMed]

35. Gu, Y.; Chen, C.; Bandopadhyay, S.; Ning, C.; Zhang, Y.; Guo, Y. Corrosion mechanism and model of pulsed DC microarc oxidation treated AZ31 alloy in simulated body fluid. Appl. Surf. Sci. 2012, 258, 6116-6126. [CrossRef] 
36. Lin, X.; Yang, X.; Tan, L.; Li, M.; Wang, X.; Zhang, Y.; Yang, K.; Hu, Z.; Qiu, J. In vitro degradation and biocompatibility of a strontium-containing micro-arc oxidation coating on the biodegradable ZK60 magnesium alloy. Appl. Surf. Sci. 2014, 288, 718-726. [CrossRef]

37. Zhang, S.F.; Zhang, R.F.; Li, W.K.; Li, M.S.; Yang, G.L. Effects of tannic acid on properties of anodic coatings obtained by micro arc oxidation on AZ91 magnesium alloy. Surf. Coat. Technol. 2012, 207, 170-176. [CrossRef]

38. Rama Krishna, L.; Poshal, G.; Jyothirmayi, A.; Sundararajan, G. Compositionally modulated CGDS + MAO duplex coatings for corrosion protection of AZ91 magnesium alloy. J. Alloys Compd. 2013, 578, 355-361. [CrossRef]

39. Rad, H.R.B.; Idris, M.H.; Kadir, M.R.A.; Farahany, S. Microstructure analysis and corrosion behavior of biodegradable Mg-Ca implant alloys. Mater. Des. 2012, 33, 88-97. [CrossRef]

40. Zhang, S.; Zhang, X.; Zhao, C.; Li, J.; Song, Y.; Xie, C.; Tao, H.; Zhang, Y.; He, Y.; Jiang, Y.; et al. Research on an Mg-Zn alloy as a degradable biomaterial. Acta Biomater. 2010, 6, 626-640. [CrossRef] [PubMed]

41. Sedelnikova, M.; Komarova, E.; Sharkeev, Y.; Tolkacheva, T.; Sheikin, V.; Egorkin, V.; Mashtalyar, D.; Kazakbaeva, A.; Schmidt, J. Characterization of the micro-arc coatings containing $\beta$-tricalcium phosphate particles on Mg-0.8Ca alloy. Metals 2018, 8, 238. [CrossRef]

42. Mogha, N.K.; Sahu, V.; Sharma, M.; Sharma, R.K.; Masram, D.T. Biocompatible $\mathrm{ZrO}_{2}$-reduced graphene oxide immobilized AChE biosensor for chlorpyrifos detection. Mater. Des. 2016, 111, 312-320. [CrossRef]

43. Zhang, S.; Bi, Y.; Li, J.; Wang, Z.; Yan, J.; Song, J.; Sheng, H.; Guo, H.; Li, Y. Biodegradation behavior of magnesium and ZK60 alloy in artificial urine and rat models. Bioact. Mater. 2017, 2, 53-62. [CrossRef] [PubMed]

44. Jin, W.; Wang, G.; Lin, Z.; Feng, H.; Li, W.; Peng, X.; Qasim, A.M.; Chu, P.K. Corrosion resistance and cytocompatibility of tantalum-surface-functionalized biomedical ZK60 Mg alloy. Corros. Sci. 2017, 114, 45-56. [CrossRef]

45. Chen, Y.; Zhang, J.; Dai, N.; Qin, P.; Attar, H.; Zhang, L.-C. Corrosion behaviour of selective laser melted Ti-TiB biocomposite in simulated body fluid. Electrochim. Acta 2017, 232, 89-97. [CrossRef]

46. Cheng, Z.; Lian, J.; Hui, Y.; Li, G. Biocompatible DCPD coating formed on AZ91D magnesium alloy by chemical deposition and its corrosion behaviors in SBF. J. Bionic Eng. 2014, 11, 610-619. [CrossRef]

47. Lu, H.B.; Zhang, L.C.; Gebert, A.; Schultz, L. Pitting corrosion of Cu-Zr metallic glasses in hydrochloric acid solutions. J. Alloys Compd. 2008, 462, 60-67. [CrossRef]

48. Cui, X.-J.; Ping, J.; Zhang, Y.-J.; Jin, Y.-Z.; Zhang, G.-A. Structure and properties of newly designed MAO/TiN coating on AZ31B Mg alloy. Surf. Coat. Technol. 2017, 328, 319-325. [CrossRef]

49. Pan, L.; Yoon, R.-H. Effects of elctrolytes on the stability of wetting films: Implications on seawater flotation. Miner. Eng. 2018, 122, 1-9. [CrossRef]

50. Li, Y.; Lu, F.; Li, H.; Zhu, W.; Pan, H.; Tan, G.; Lao, Y.; Ning, C.; Ni, G. Corrosion mechanism of micro-arc oxidation treated biocompatible AZ31 magnesium alloy in simulated body fluid. Prog. Nat. Sci. Mater. Int. 2014, 24, 516-522. [CrossRef]

51. Kim, H.-W.; Knowles, J.C.; Kim, H.-E. Hydroxyapatite/poly(e-caprolactone) composite coatings on hydroxyapatite porous bone scaffold for drug delivery. Biomaterials 2004, 25, 1279-1287. [CrossRef] [PubMed]

52. Mohd Yusoff, M.F.; Abdul Kadir, M.R.; Iqbal, N.; Hassan, M.A.; Hussain, R. Dipcoating of poly ( $\varepsilon$-caprolactone)/hydroxyapatite composite coating on Ti6Al4V for enhanced corrosion protection. Surf. Coat. Technol. 2014, 245, 102-107. [CrossRef]

53. Curioni, M.; Salamone, L.; Scenini, F.; Santamaria, M.; Di Natale, M. A mathematical description accounting for the superfluous hydrogen evolution and the inductive behaviour observed during electrochemical measurements on magnesium. Electrochim. Acta 2018, 274, 343-352. [CrossRef]

54. Akbari, E.; Di Franco, F.; Ceraolo, P.; Raeissi, K.; Santamaria, M.; Hakimizad, A. Electrochemically-induced $\mathrm{TiO}_{2}$ incorporation for enhancing corrosion and tribocorrosion resistance of PEO coating on $7075 \mathrm{Al}$ alloy. Corros. Sci. 2018. [CrossRef]

55. Wang, Z.B.; Hu, H.X.; Zheng, Y.G.; Ke, W.; Qiao, Y.X. Comparison of the corrosion behavior of pure titanium and its alloys in fluoride-containing sulfuric acid. Corros. Sci. 2016, 103, 50-65. [CrossRef]

56. Qiao, Y.X.; Zheng, Y.G.; Ke, W.; Okafor, P.C. Electrochemical behaviour of high nitrogen stainless steel in acidic solutions. Corros. Sci. 2009, 51, 979-986. [CrossRef]

57. Li, Z.; Gu, X.; Lou, S.; Zheng, Y. The development of binary Mg-Ca alloys for use as biodegradable materials within bone. Biomaterials 2008, 29, 1329-1344. [CrossRef] [PubMed] 
58. Lederer, S.; Lutz, P.; Fürbeth, W. Surface modification of Ti $13 \mathrm{Nb} 13 \mathrm{Zr}$ by plasma electrolytic oxidation. Surf. Coat. Technol. 2018, 335, 62-71. [CrossRef]

59. Pan, Y.K.; Chen, C.Z.; Wang, D.G.; Lin, Z.Q. Preparation and bioactivity of micro-arc oxidized calcium phosphate coatings. Mater. Chem. Phys. 2013, 141, 842-849. [CrossRef]

60. García Rodenas, L.; Palacios, J.M.; Apella, M.C.; Morando, P.J.; Blesa, M.A. Surface properties of various powdered hydroxyapatites. J. Colloid Interface Sci. 2005, 290, 145-154. [CrossRef] [PubMed]

61. Zhang, E.; Yin, D.; Xu, L.; Yang, L.; Yang, K. Microstructure, mechanical and corrosion properties and biocompatibility of Mg-Zn-Mn alloys for biomedical application. Mater. Sci. Eng. C 2009, 29, 987-993. [CrossRef]

62. Lin, X.; Tan, L.; Zhang, Q.; Yang, K.; Hu, Z.; Qiu, J.; Cai, Y. The in vitro degradation process and biocompatibility of a ZK60 magnesium alloy with a forsterite-containing micro-arc oxidation coating. Acta Biomater. 2013, 9, 8631-8642. [CrossRef] [PubMed]

(C) 2018 by the authors. Licensee MDPI, Basel, Switzerland. This article is an open access article distributed under the terms and conditions of the Creative Commons Attribution (CC BY) license (http://creativecommons.org/licenses/by/4.0/). 